Article

\title{
Smart and Renewable Energy System to Power a Temperature-Controlled Greenhouse ${ }^{\dagger}$
}

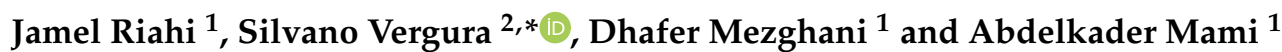

1 UR-LAPER, Faculty of Sciences of Tunis, University of Tunis El Manar Tunis, Tunis 1068, Tunisia; riahijamel100@gmail.com (J.R.); dhafer.mezghanni@gmail.com (D.M.); abdelkader.mami@fst.utm.tn (A.M.)

2 Department of Electrical and Information Engineering, Polytechnic University of Bari, st. E. Orabona 4, I-70125 Bari, Italy

* Correspondence: silvano.vergura@poliba.it; Tel.: +39-080-5963590

$+\quad$ This paper is an extended version of our paper published in 2020 IEEE-EEEIC International Conference on Environment and Electrical Engineering, Madrid, Spain, 9-12 June 2020; pp. 1-6.

Citation: Riahi, J.; Vergura, S.;

Mezghani, D.; Mami, A. Smart and

Renewable Energy System to Power a Temperature-Controlled Greenhouse. Energies 2021, 14, 5499. https://doi. org/10.3390/en14175499

Academic Editors:

Vincenzo d'Alessandro and

Pierluigi Guerriero

Received: 27 July 2021

Accepted: 31 August 2021

Published: 3 September 2021

Publisher's Note: MDPI stays neutral with regard to jurisdictional claims in published maps and institutional affiliations.

Copyright: (C) 2021 by the authors. Licensee MDPI, Basel, Switzerland. This article is an open access article distributed under the terms and conditions of the Creative Commons Attribution (CC BY) license (https:/ / creativecommons.org/licenses/by/ $4.0 /)$.

\begin{abstract}
This paper presents the modeling and simulation of a Multi-Source Power System (MSPS) composed of two renewable energy sources and supported by a Battery Energy Storage System (BESS) - to supply the ventilation and heating system for a temperature-controlled agricultural greenhouse. The first one is a photovoltaic (PV) generator connected to a DC/AC inverter and the second one is a wind turbine connected to a Permanent Magnet Synchronous Generator (PMSG). The temperature contribution in the model of the PV generator is deeply studied. A Maximum Power Point Tracking (MPPT) control based on fuzzy logic is used to drive a SEPIC converter to feed the maximum power to the greenhouse actuators. The operation of the actuators (ventilation and heating systems), on the basis of the mismatch between the internal temperature and the reference one, is controlled by a PI controller optimized by fuzzy logic, for more robust results. The simulation of the system is carried out in a Matlab/Simulink environment and its validation is based on the comparison between the simulated and experimental data for a test greenhouse, located in the Faculty of Science in Tunis. The results show that the proposed system provides an efficient solution for controlling the microclimate of the agricultural greenhouse in different periods of the year.
\end{abstract}

Keywords: multi-source power systems; battery storage systems; PV plant; wind plant; SEPIC converter; greenhouse; fuzzy logic controller; Matlab; Simulink

\section{Introduction}

Electric energy generation systems based on renewable sources such as wind and solar are a valid alternative solution to fossil-fuel-based systems. Indeed, wind and photovoltaic systems have been booming lately and have become more and more accessible in terms of technologies and costs. Once installed, these systems can be independent of any source or network and have the advantage of being able to be positioned close to consumer sites.

A combined power system based on Renewable Energy Sources (RES) is an effective solution for controlling the internal climate of an agricultural greenhouse, because it can ensure the power necessary for its automatic operation [1,2]. Combined energy systems in different applications are known. Reference [3] presented a wind-PV generator coupled with a DC load, while [4] developed a model of a PV-wind system implemented in Matlab/Simulink. Reference [5] focused on the converter design, while [6] presented a design of a controller for the energy sources. In addition, it is necessary to monitor efficiency over time to promptly detect malfunctions before failures occur. A PV system can be easily monitored if it is equipped with a datalogger that stores the electrical parameters $[7,8]$. In the absence of a datalogger, the correct operation of PV systems can be checked using infrared analysis [9] and/or simulation tools [10,11]. Renewable energy is largely used in the industrial sector. For example, the authors in [12] developed a combined energy 
system for vehicle control, whereas other researchers presented a ventilation system of an agricultural greenhouse powered by a photovoltaic generator [13], or a control strategy for the indoor air temperature [14]. The agricultural field is nowadays an important target for researchers due to global warming, the necessity of water for cultivation, and the necessity of a good microclimate inside greenhouses. According to the Food and Agriculture Organization of the United Nations, food production has increased by more than $100 \%$ in the last 30 years and a further $60 \%$ increase is expected by 2050 [15,16]. For these reasons, many researchers are also focusing on the electrical issues of agricultural greenhouses; in fact, to guarantee a correct microclimate for the crops grown, electrical equipment (motor for ventilation/heating and/or water pumps) is needed. Proposed solutions are often based on a combination of power sources, supported by techno-economic analyses [17-19]. Sometimes a diesel motor is considered [17], but often a total renewable energy system is preferred [18,19]. An interesting review of solar technologies in agricultural greenhouses is available in [20]. The choice of power source is the first step, but their management [21,22] and optimization [23] is also important.

This paper focuses on the possibility of supplying the electricity requirements of an agricultural greenhouse by means of renewable energy sources in order to make it autonomous from the point of view of energy. As greenhouses require fixed temperatures during the day and the night, the electrical actuators must be active for the whole day, even if not at the same time. Therefore, the choice of photovoltaic system alone is not ideal because it should produce the energy necessary for the whole day in a few hours, the amount of which would vary during the year; hence, it should be sized for the worst-case scenario, which is winter. Furthermore, even the choice of wind power plant alone is not ideal, due to the great unpredictability of the wind; therefore, it must be sized for the worst case, which is a day with little wind. This implies that an optimal solution consists in a combination of several energy sources, possibly chosen from renewable energy sources. However, the combination of multiple power sources requires more complex control of the energy flows between the sources and loads. For these reasons, this paper proposes a combined wind-PV power supply system for a temperature-controlled greenhouse. The heating and ventilation system to maintain the temperature constant is driven by a fuzzy MPPT strategy. Energy consumption is reduced by coupling a photovoltaic system with a wind generator. This approach offers a good solution in any period. Moreover, the power delivered by the RES system is enough for the operation of the different actuators of the greenhouse. This context is explained by the presence of wind energy when there is no photovoltaic energy; especially during cold periods (night), the greenhouse requires a more intensive heating rate. The agricultural greenhouse is placed close to the sea; thus, the high wind speed allows for a great production of wind energy. Temperature has a double role. It affects the operation of the PV system, because the power produced by the PV modules depends mainly on the irradiance and temperature. Moreover, a fixed temperature value inside the greenhouse is the target for a good microclimate for cultivation. Great attention is then paid to the thermal contribution in the modeling of the photovoltaic cell. The power system is also equipped with a Battery Energy Storage System (BESS) that support the PV-wind system, when the load demand exceeds the produced energy, as happens during the night, because only the wind plant works. Due to the presence of the BESS, the control system needs to define the constraints for charging and discharging the battery, considering the bidirectional energy flows from and to the battery. Control of the actuators is the main point of interest of this paper with respect to the state of the art. Further details can be found in Section 3.2 and in the results. Control of the ventilation and heating system is done using a PI controller Optimized by Fuzzy Logic (PIOFL) strategy. In the literature, several researchers have used on/off control for agricultural greenhouse actuators, but this strategy is not convenient for this type of system, because it reduces the life of the actuators and is more expensive from an energy point of view. Instead, the proposed control works better, because the speed variation is continuous and avoids successive starting/stopping of the motors. In summary, the paper is constituted by two main parts: the power sources 
and the control. The choice and size of the power sources is better described in [1], of which this paper is an extension. Instead, the control part represents the main contribution of this paper.

The paper is organized as follows. The modeling of the main components constituting the global system, including the BESS and the greenhouse modeling, is presented in Section 2. The control strategy of the combined energy systems and of the heating/ventilation system is described in Section 3. The simulation results are discussed in Section 4, whereas the final section contains the Conclusions.

\section{Modeling of the Energy System}

The proposed energy system is composed of a photovoltaic generator based on KANEKA GSA060 PV modules, a wind generator, a storage system battery bank, SEPIC converters controlled by a fuzzy MPPT strategy, and an inverter. They are wired with a ventilation and heating system composed by an asynchronous motor, controlled by a vector control optimized by fuzzy logic. The main scheme, implemented in the Matlab/Simulink environment, is shown in Figure 1.

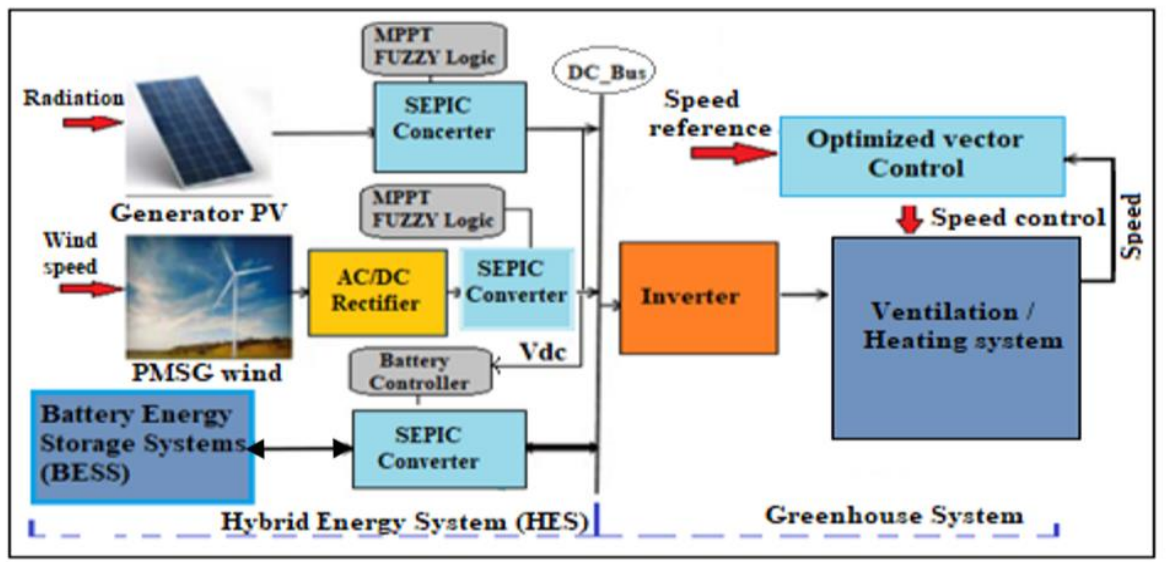

Figure 1. Conceptual scheme of the global system.

The proposed model is based on a real experimental energy system, available in the Faculty of Sciences in Tunis, and it is described in Section 2.7. The following subsections describe the model of the components of that real system. Particularly, Section 2.1 models the PV cell and module, highlighting how to account for the influence of temperature on the several components.

\subsection{Model of the PV Generator}

A PV module is composed of several PV cells connected in series to increase the value of the total voltage, and several PV modules can be connected in parallel to increase the value of the total current. The single diode model of a PV cell is shown in Figure 2, where $R_{S}$ and $R_{s h}$ are the series- and shunt-resistors.

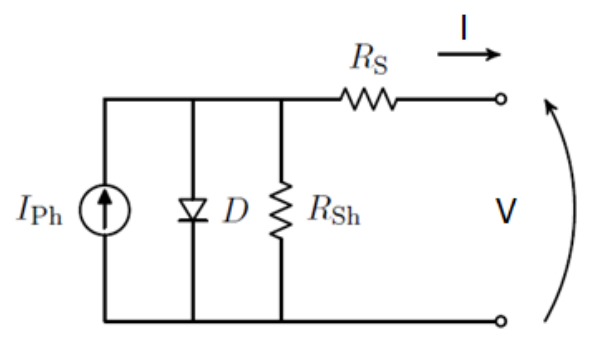

Figure 2. Electric model of a PV cell. 
According to the LKC in the upper node in Figure 2, it results:

$$
I=I_{p h}-I_{D}-I_{R s h}
$$

where $I_{p h}$ is the photodiode current, later defined.

The current passing through the resistor $I_{R s h}$ is given by:

$$
I_{R s h}=\left(V+I R_{s}\right) / R_{s h}
$$

The diode current is:

$$
I_{D}=I_{S}\left[e^{\left(\left(V+I R_{S}\right) / n V_{t}\right)}-1\right]
$$

where $I_{S}$ is the reverse saturation current, defined as [24]:

$$
I_{S}=K_{1} \times T_{c}^{3} e^{-\frac{E_{g}}{K T_{c}}}
$$

where

$$
V_{t}=\frac{K T_{c}}{q}
$$

K: Boltzmann's constant $\left(1.381 \times 10^{-23} \mathrm{~J} / \mathrm{K}\right)$;

$T_{c}$ : absolute cell temperature in Kelvin;

$q$ : electron charge $\left(1.602 \times 10^{-19} \mathrm{C}\right)$;

$K_{1}$ : constant $\left(1.2 \mathrm{~A} / \mathrm{cm}^{2} \mathrm{~K}^{3}\right)$;

$E_{g}$ : band energy gap (for crystalline silicon $=1.12 \mathrm{eV}$ );

$n$ : diode ideality factor.

By grouping the previous equations, the current-voltage (I-V) curve is:

$$
I=I_{p h}-I_{S}\left[e^{\left(\left(V+I R_{S}\right) / n V_{t}\right)}-1\right]-\frac{V+I R_{S}}{R_{s h}}
$$

$I_{p h}$ can be extracted from the Short-Circuit (SC) condition. In fact, the $I_{S C}$ current is the maximum current generated by the cell. It is produced when $V=0$. From (6) and remembering that $R_{s} \ll R_{p}$, it results $I_{p h} \approx I_{S C}$.

All the parameters are affected by the solar radiation $G$ and the air temperature $T_{a}$. Therefore, Equation (6) and the values of $R_{s}, R_{s h}, n, I_{s}, I_{p h}$ are valid for a fixed environment condition. Moreover, these values are not available in manufacturer datasheets of the PV modules in any condition, because these other specifications are available: rated peak power $\left(P_{n}\right)$, open-circuit voltage $\left(V_{o c}\right)$, short-circuit current $\left(I_{s c}\right)$, voltage and current in MPP $\left(V_{m p p}\right.$ and $\left.I_{m p p}\right)$, temperature coefficient for the short circuit current $\left(\alpha_{I_{s c}}\right)$, and temperature coefficient for the open circuit voltage $\left(\alpha_{V_{o c}}\right)$. Moreover, these values regard the whole PV module and not the single PV cell. Nevertheless, the number of series- and parallelconnected PV cells is usually available in the PV module datasheet, thus cell voltage and current are:

$$
\begin{gathered}
V_{\text {cell }}=\frac{V_{\text {module }}}{N_{s}} \\
I_{\text {cell }}=\frac{I_{\text {module }}}{N_{p}}
\end{gathered}
$$

with $N_{s}$ the number of series-connected cells and $N_{p}$ the number of parallel-connected cells. Finally, to compare the performance of several PV modules, the declared values are evaluated under standard test conditions (STCs), i.e., $G=1000 \mathrm{~W} / \mathrm{m}^{2}, T_{a}=25^{\circ} \mathrm{C}$, air wind of $1 \mathrm{~m} / \mathrm{s}$ and air mass of 1.5. Instead, the nominal module operating temperature (NMOT) is defined for $800 \mathrm{~W} / \mathrm{m}^{2}$ and cell temperature $T_{c}=20^{\circ} \mathrm{C}$. The NMOT verifies the following equation:

$$
T_{c}=T_{a}+\frac{G}{800} \times(\mathrm{NMOT}-20)
$$


In summary, the circuit of Figure 2 is valid after calculating the parameters in the operating condition, i.e., under the actual solar radiation and air temperature. Therefore, the photodiode current depends on both $G$ and $T_{a}$ :

$$
I_{P h}=G_{p u} \cdot\left[I_{s c}^{o}+\alpha_{I_{s c}} \cdot\left(T_{c}-25\right)\right]
$$

where $G_{p u}=G / 1000$ is the irradiance normalized to the STC value, $I_{s c}^{o}$ is the short circuit current at STC, $\alpha_{I_{s c}}$ is the current-temperature coefficient at STC, $\Delta T=\left(T_{\mathcal{C}}-25\right)$ is the temperature difference with respect to the STC.

Analogous expression of Equation (10) is valid for $I_{m p p}$ :

$$
I_{m p p}=G_{p u} \cdot\left[I_{m p p}^{o}+\alpha_{I_{s c}} \cdot\left(T_{c}-25\right)\right]
$$

The second term in Equation (6) depends on the dark saturation current, $I_{S}$, which in turn depends on the cell temperature (see Equation (4)), but also on the series resistance $R_{s}$. Thus, it can be represented as:

$$
\beta \cdot e^{\gamma \cdot\left(V+\alpha_{V_{o c}} \cdot \Delta T-V_{o c}^{o}\right)}
$$

where $V_{o c}^{o}$ is the open circuit voltage in STC, while the parameters $\beta$ and $\gamma$ will be calculated later. Equation (12) highlights the temperature dependence of the $V_{o c}$ [25]:

$$
V_{o c}=V_{o c}^{o}-\alpha_{V_{o c}} \cdot \Delta T
$$

Since $V_{m p p}$ and $V_{o c}$ differ by less than $15 \%$, the following is also valid:

$$
V_{m p p}=V_{m p p}^{o}-\alpha_{V_{o c}} \cdot \Delta T
$$

The third term of Equation (6) considers the dissipative phenomena [26] inside the PV cell, by means of the series- and shunt- resistors. As better explained in [27-29], $R_{S}$ defines the slope of the I-V curve in open-circuit state, while $R_{s h}$ defines the slope in short-circuit state; their values can be approximated as:

$$
\begin{gathered}
R_{s h}=\frac{V_{m p p}^{o}-\alpha_{V_{o c}} \cdot \Delta T}{G_{p u} \cdot \frac{\left(I_{s c}^{o}-I_{m p p}^{o}\right)}{2}}=\frac{V_{s h}}{I_{s h}} \\
R_{s}=\frac{\frac{\left(V_{o c}^{o}-V_{m p p}^{o}\right)}{4}}{G_{p u} \cdot\left(I_{m p p}^{o}+\alpha_{I_{s c}} \cdot \Delta T\right)}=\frac{V_{s}}{I_{s}}
\end{gathered}
$$

Now, substituting Equations (10) and (12) in (6), and considering (15)-(16), it results:

$$
I \cdot\left(1+\frac{R_{s}}{R_{s h}}\right)=G_{p u} \cdot\left(I_{s c}^{o}+\alpha_{I_{s c}} \cdot \Delta T\right)-\beta \cdot e^{\gamma \cdot\left(V+\alpha_{V_{o c}} \cdot \Delta T-V_{o c}^{o}\right)}-\frac{V}{R_{s h}}
$$

Parameters $\beta$ and $\gamma$ are calculated [28], imposing the constraints at the three characteristic points: short-circuit state, open-circuit state, and the maximum power point. Their values are:

$$
\begin{gathered}
\beta=G_{p u} \cdot\left(I_{s c}^{o}+\alpha_{I_{s c}} \cdot \Delta T\right)-\frac{V_{o c}^{o}-\alpha_{V_{o c}} \cdot \Delta T}{R_{s h}} \\
\gamma=\frac{1}{V_{m p p}^{o}-V_{\mathrm{oc}}^{o}} \cdot \log \frac{G_{p u} \cdot\left(p I_{s c}^{o}-I_{m p p}^{o}\right)-(1-p) \cdot \alpha_{I_{s c}} \cdot \Delta T-\frac{p \cdot\left(V_{m p p}^{o}-\alpha_{V_{o c}} \cdot \Delta T\right)}{R_{s h}}}{p \cdot\left(G_{p u} \cdot\left(I_{s c}^{o}+\alpha_{I_{s c}} \cdot \Delta T\right)-\frac{V_{o c}^{o}-\alpha_{V_{o c}} \cdot \Delta T}{R_{s h}}\right)}
\end{gathered}
$$

where $p=\frac{R_{s h}}{R_{s}+R_{s h}}=\frac{8 \cdot\left(V_{m p p}^{o}-\alpha_{V_{o c}} \cdot \Delta T\right) \cdot\left(I_{m p p}^{o}+\alpha_{I s c} \cdot \Delta T\right)}{8 \cdot\left(V_{m p p}^{o}-\alpha_{V_{o c}} \cdot \Delta T\right) \cdot\left(I_{m p p}^{o}+\alpha_{I s c} \cdot \Delta T\right)+\left(V_{o c}^{o}-V_{m p p}^{o}\right) \cdot\left(I_{s c}^{o}-I_{m p p}^{o}\right)}$. 
These parameters depend on both the irradiance and the air temperature, so they can describe each operating point, whatever the environmental condition. Figure 2, after the mathematical manipulations, becomes as in Figure 3, where the contributions of irradiance and temperature are highlighted. $\Delta T$ is modelled with two series-connected voltage sources, and it controls four voltage-controlled sources: $I_{s c}^{o}$ and $I_{m p p}^{o}$ (with the coefficient $\alpha_{I_{s c}}$ ), and $V_{o c}^{o}$ and $V_{m p p}^{o}$ (with the coefficient $\alpha_{V_{o c}}$ ). The resistance $G$ represents the solar radiance. In particular, the term $I_{x}=G_{p u} \cdot\left(I_{s c}^{o}+\alpha_{I_{s c}} \cdot \Delta T\right)=\frac{G}{G+(1000-G)} \cdot\left(I_{s c}^{o}+\alpha_{I_{s c}} \cdot \Delta T\right)$ of Equation (18) is calculated with a current divider. The circuit in Figure 3 models a single PV cell, but it can be used for a PV module by using Equations (7) and (8).
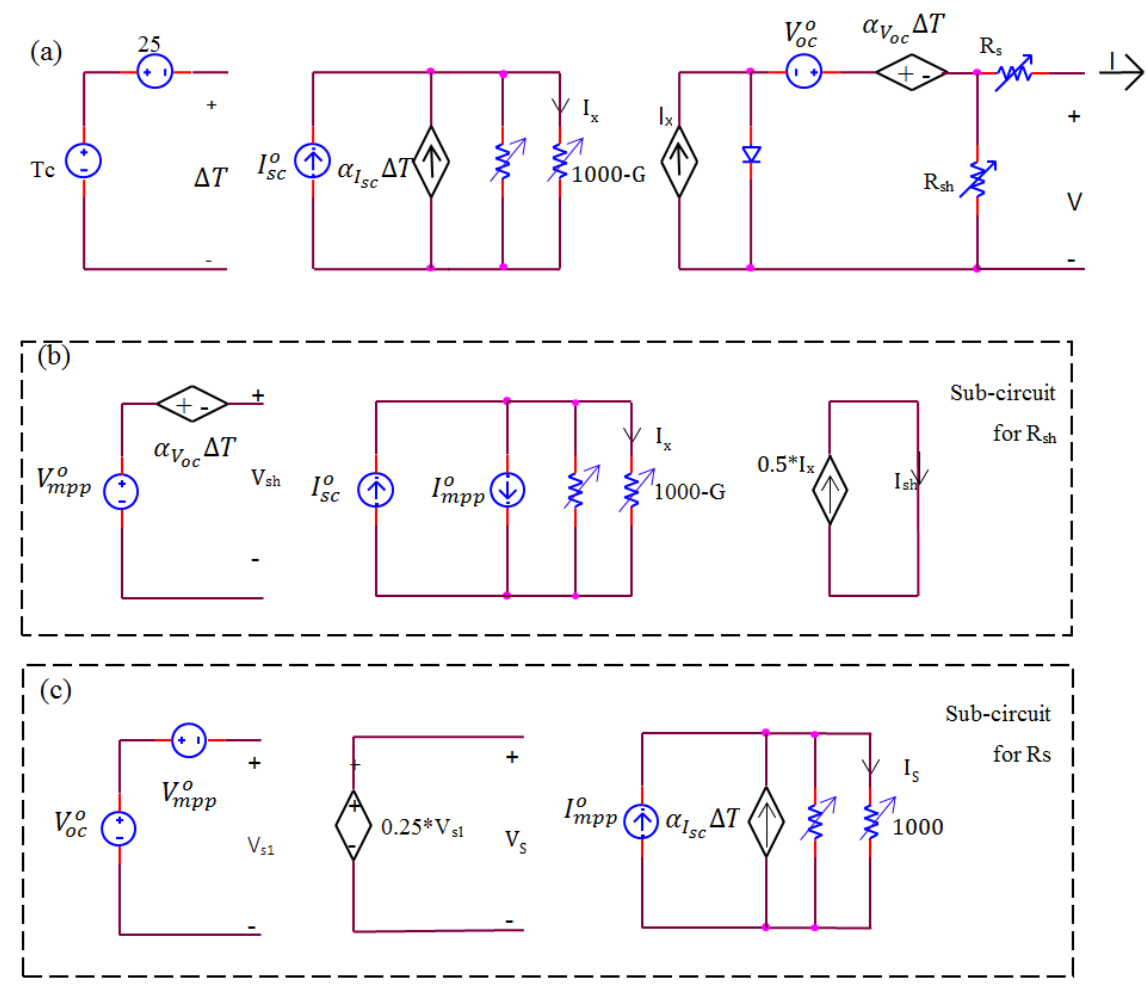

Figure 3. Circuit of a PV cell in any environment condition.

\subsection{Model of the Wind Turbine}

The wind turbine system is composed by a wind turbine, a PMSG and an AC/DC rectifier. The wind turbine power, $p_{\mathrm{w}}$, is described by the equation:

$$
p_{w}=\frac{1}{2} \rho R^{2} V_{w}^{3} C_{p}(\beta, \lambda)
$$

where $\rho=1.225 \mathrm{Kg} / \mathrm{m}^{3}, R$ is the radius of the wind turbine, $\beta$ is the pitch angle, $C_{p}$ is the power coefficient, $V_{w}$ the wind speed, and $\lambda$ symbolizes the tip speed ratio defined by:

$$
\lambda=\frac{\omega_{t u r b} R}{V_{w}}
$$

with $\omega_{\text {turb }}$ the angular velocity of the wind turbine rotor.

The mathematical model of the most used PMSG generator in the wind turbine is described by the following differential equation in the $(\mathrm{d}, \mathrm{q})$ reference [30]:

$$
\begin{gathered}
V_{q}=R_{s} i_{q}-L_{q} \frac{d i_{q}}{d t}+\omega_{e} L_{d} i_{d}+\omega_{e} \lambda_{m} \\
V_{d}=R_{s} i_{d}-L_{d} \frac{d i_{d}}{d t}+\omega_{e} L_{q} i_{q}
\end{gathered}
$$


The electromagnetic torque is defined as [31]:

$$
T_{e m}=\frac{3 P}{2} \cdot\left[\left(L_{d}-L_{q}\right)\right] i_{q} i_{d}-i_{q} \lambda_{m}
$$

The electrical angular speed $\omega_{e}$ depends on the number of pole pairs $\mathrm{P}$, whereas the mechanical angular velocity $\omega_{\text {turb }}$ satisfies the equation:

$$
\omega_{e}=\frac{P}{2} \omega_{t u r b}
$$

Many types of rectifiers are used in the wind system. The PMSG is connected to a three-phase non-controlled rectifier. The PMSG electrical behavior is described by the following equations [32], VDC being the DC output voltage:

$$
\begin{gathered}
V=V_{m} \sin (w t) \\
V_{\mathrm{DC}}=\frac{3 \sqrt{3}}{\pi} V_{m}=\lambda P \omega_{e}\left(\frac{3 \sqrt{6}}{\pi}\right) \\
I_{\mathrm{DC}}=\frac{\pi}{\sqrt{6}} I_{A}
\end{gathered}
$$

\subsection{Model of the Battery Energy Storage System}

The BESS consists of a bank of lithium-ion type batteries used to reduce power fluctuations from renewable energy sources and can support the stability of the electrical system. The operation of the storage system is described by the following equation [33]:

$$
\begin{gathered}
E_{\text {charge }}(t)=E_{\text {Batt }}(t-1)+\left(E_{H E S}(t)-E_{L}(t)\right) \cdot \eta_{\text {Batt }} \\
E_{\text {discharge }}(t)=E_{\text {Batt }}(t-1)-\left(E_{L}(t)-E_{H E S}(t)\right)
\end{gathered}
$$

where $E_{L}$ is the load demand (W), $E_{\text {HES }}$ is the power delivered from the MSPS (W), $\eta_{\text {Batt }}$ is the battery efficiency (\%), $E_{\text {charge }}$ and $E_{\text {discharge }}$ are the battery power in the charging and discharging periods, respectively.

The battery bank capacity can be calculated according to the equation [34]:

$$
C_{\text {Batt }}=D A \cdot\left(E_{L}-E_{H E S}\right) /\left(\eta_{\text {inv }} \cdot \eta_{\text {Batt }} \cdot D O D\right)
$$

where $D A$ is the Daily Autonomy, $\eta_{i n v}$ is the inverter efficiency (\%) and DOD is the Depth Of Discharge of the battery (\%), that varies from $60 \%$ to $100 \%$.

Battery charging and discharging are related to the State of Charge (SOC), which is constrained by:

$$
\begin{gathered}
S O C_{\text {min }} \leq S O C(t) \leq S O C_{\text {max }} \\
S O C_{\text {min }}=(1-D O D)
\end{gathered}
$$

where $S O C_{\max }$ is the upper limit fixed to $100 \%$ and $S O C_{\min }$ is the lower limit.

The BESS is connected to the DC bus via the bi-directional converter (Figure 1) and allows compensation and minimization of output power fluctuations due to the energy conversion system engaged for wind and solar radiation.

\subsection{SEPIC Buck Boost Converter}

A converter is chosen for the purpose of modifying the voltage delivered by the power sources (PV generator and wind turbine) and guaranteeing the maximum power. In this case, a SEPIC buck-boost inverter is used (Figure 4), whose characteristics are reported in $[35,36]$. The specifications of the converter have been set for the laboratory test and the values of the main components are reported in Table 1. 


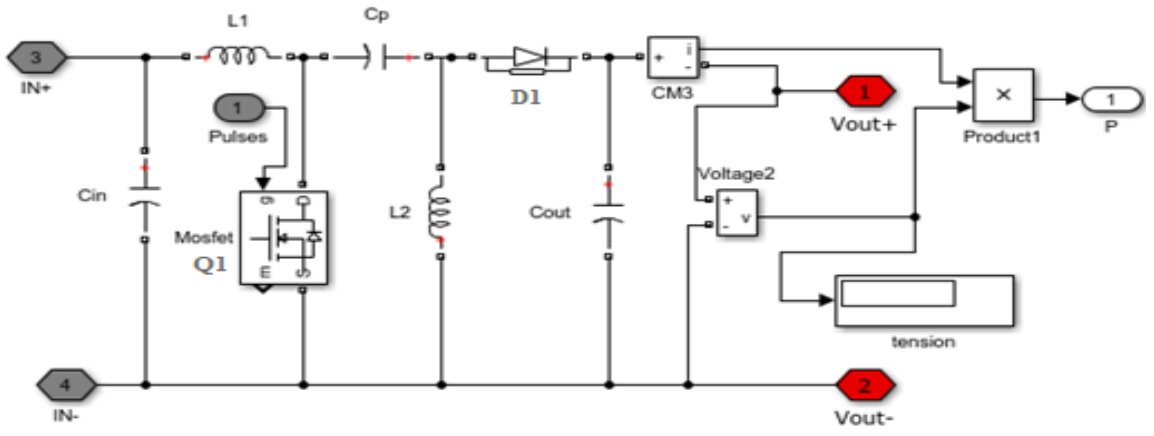

Figure 4. Simulink model of the SEPIC converter.

Table 1. Values of the main components of the SEPIC.

\begin{tabular}{cc}
\hline Component & Value \\
\hline Cin, Cout & $440 \mathrm{uF}$ \\
Cp & $10 \mathrm{uF}$ \\
L1, L2 & $47 \mathrm{uH}$ \\
\hline
\end{tabular}

\subsection{Fuzzy Logic for the MPPT}

This subsection discusses the design of the MPPT strategy, based on a fuzzy corrector and on the principle of Perturbation and Observation (P\&O). For the fuzzification step, the input variables are the incremental voltage, $E_{V}(k)$, and the incremental power, $E_{P}(k)$, for the generic k-th step, defined on the basis of the current and previous samples:

$$
\begin{gathered}
E_{V}(k)=V_{p}(k)-V_{P}(k-1) \\
E_{P}(k)=P_{P}(k)-P_{P}(k-1)
\end{gathered}
$$

The linguistic variables are reported in Figures 5 and $6(\mathrm{P}=$ positive; $\mathrm{Z}=$ approximately zero; $\mathrm{N}=$ negative). Instead, the inference rules are reported in Table 2. The center of gravity method is used for the defuzzification. For this case, the unique output variable is the change of the duty cycle D (see the third column of Table 2 and Figure 7).

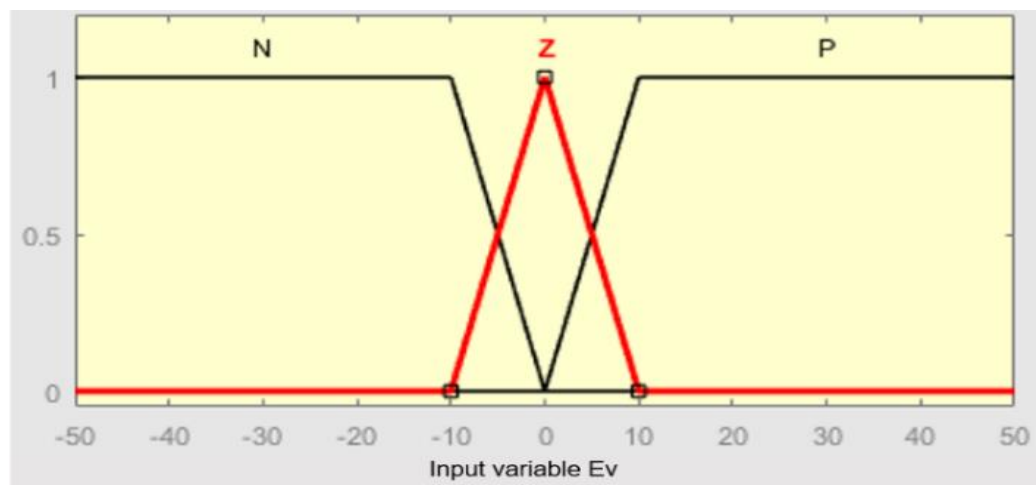

Figure 5. Linguistic variable $E_{V}(k)$. 


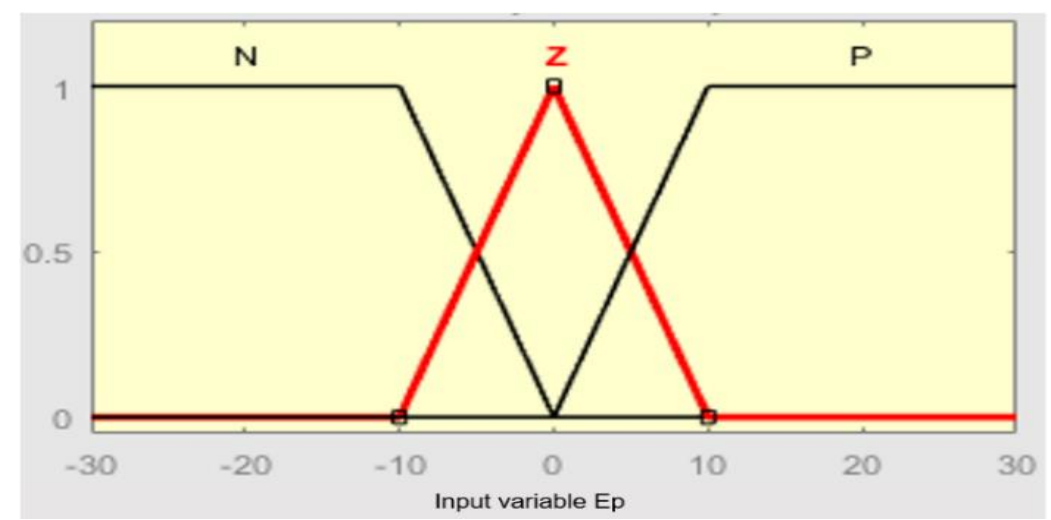

Figure 6. Linguistic variable $E(k)$.

Table 2. Rules of inference.

\begin{tabular}{cccc}
\hline Rules & $\mathbf{E}_{\mathbf{v}}$ & $\mathbf{E}_{\mathbf{p}}$ & $\mathbf{D}$ \\
\hline 1 & $\mathrm{P}$ & $\mathrm{P}$ & $\mathrm{P}$ \\
2 & $\mathrm{~N}$ & $\mathrm{P}$ & $\mathrm{P}$ \\
3 & $\mathrm{Z}$ & $\mathrm{P}$ & $\mathrm{P}$ \\
4 & $\mathrm{Z}$ & $\mathrm{Z}$ & $\mathrm{Z}$ \\
5 & $\mathrm{~N}$ & $\mathrm{Z}$ & $\mathrm{P}$ \\
6 & $\mathrm{P}$ & $\mathrm{Z}$ & $\mathrm{N}$ \\
7 & $\mathrm{P}$ & $\mathrm{N}$ & $\mathrm{N}$ \\
8 & $\mathrm{~N}$ & $\mathrm{~N}$ & $\mathrm{P}$ \\
9 & $\mathrm{Z}$ & $\mathrm{N}$ & $\mathrm{P}$ \\
\hline
\end{tabular}

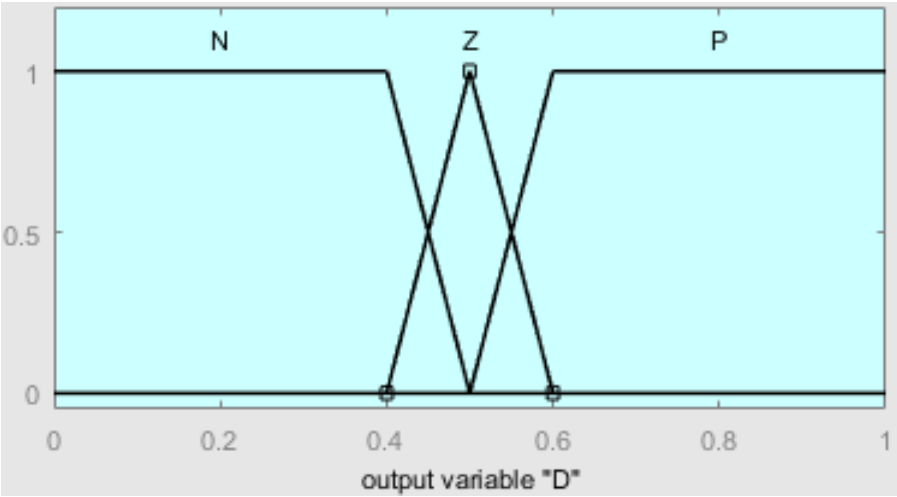

Figure 7. Output of the linguistic variable $\mathrm{D}(\mathrm{k})$.

\subsection{Greenhouse Model}

The agricultural greenhouse is a complex system, used for off-season agricultural production to ensure a favorable indoor climate. Temperature is one of the most important parameters in a greenhouse, and a heating and ventilation system is used to achieve an efficient control of the indoor temperature. This section studies a dynamic model developed in [37] and based on thermodynamic laws, and it is coupled with a heating and ventilation system supplied by an MSPS. The agricultural greenhouse is modeled as a thermodynamic system, where different heat transfers occur from several energy exchanges between the inside and outside of the greenhouse. The temperature inside the greenhouse, as discussed in $[37,38]$, must satisfy the Equation:

$$
\rho_{a} C_{a} v \frac{d \text { Tin }}{d t}=Q^{\text {short }}+Q^{\text {conv,cond }}+Q^{\text {infiltration }}-Q^{\text {long }}+Q^{\text {heater }}-Q^{\text {ventilation }}
$$


where $\rho_{a}$ is the air density equal to $1.225\left[\mathrm{Kg} / \mathrm{m}^{3}\right], C_{a}$ is the air heat capacity equal to 1.003 $[\mathrm{kJ} / \mathrm{kg} \mathrm{K}]$, and $\frac{d T i n}{d t}$ is the variation of the internal temperature. An exhaustive explanation of the other terms is reported in [36].

\subsection{Real Experimental Greenhouse in the Faculty of Sciences in Tunis}

The experimental greenhouse is in the North of Tunisia $\left(36^{\circ} 43^{\prime} 10.25^{\prime \prime} \mathrm{N}\right)$ and presents a typical model for greenhouses located in the Mediterranean area. It is a small-capel of the semi-insulated type and occupies an area equal to $14.8 \mathrm{~m}^{2}$ (width $3.7 \mathrm{~m}$, length $4 \mathrm{~m}$, ridge height $3 \mathrm{~m}$ ) and a volume of $36 \mathrm{~m}^{3}$ (Figure 8 ). This real greenhouse has been used to experimentally validate the agricultural greenhouse system, and to validate the operation of the actuators: a $705 \mathrm{~W}$ power fan and a $1000 \mathrm{~W}$ heating system. We tested an MSPS coupled by a storage system with real data (wind speed and solar radiation) to ensure the power consumed by the actuators, which control the interior temperature. In this test, the plant under cultivation is the tomato, and the optimal temperatures are $24{ }^{\circ} \mathrm{C}$ during the day and $15^{\circ} \mathrm{C}$ during the night.

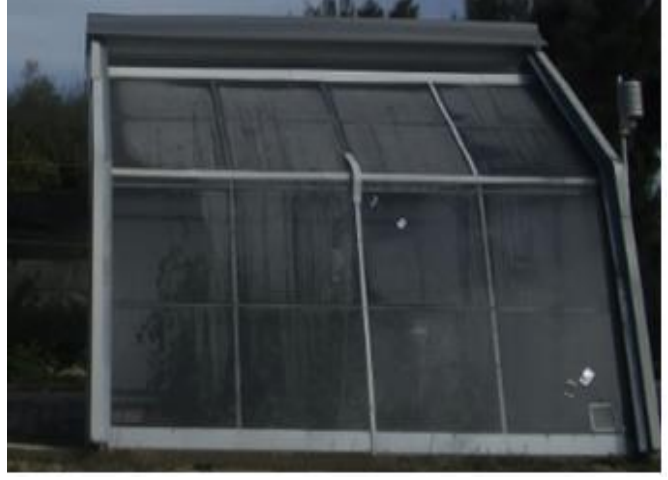

(a)

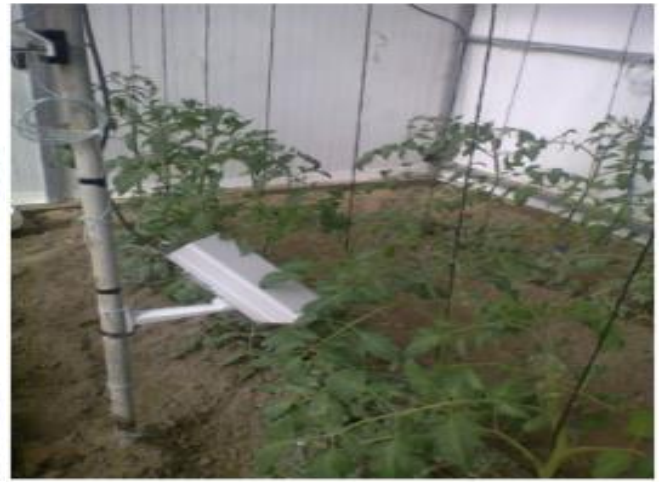

(b)

Figure 8. (a) Greenhouse; (b) Greenhouse internal area with tomato plants.

\section{Control Strategy of the Global System}

\subsection{Control of the MSPS and BESS}

This section presents the control strategy to manage the produced energy and to coordinate the interactions among the devices. The energy source is the combination of a photovoltaic system and a wind system, whereas the battery represents the energy storage system. The use of the battery bank is useful to compensate the mismatch between the power demanded by the load and the power generated by the MSPS. Therefore, three operating conditions can be observed:

- $\quad$ Power generated by the MSPS exceeds the power required by the load: the excess is stored in the battery bank and, when the battery bank will be full, the further energy will be dissipated in a load shedding system, which is a resistor in this study.

- Generated power is equal to the power required by the load: the produced power is entirely injected into the DC bus to the load.

- $\quad$ Power delivered by the MSPS is insufficient and the battery is charged: the missing power will be supplied by the battery storage system and the battery bank will be controlled to be activated when the SOC state is in the operating range.

The proposed control strategy (Figure 9) allows optimization of the produced energy and is reliable in regulating the power flow from and to the battery system, taking into account the battery SOC level and the power offset between the power demanded by the load and the power generated by the MSPS. 


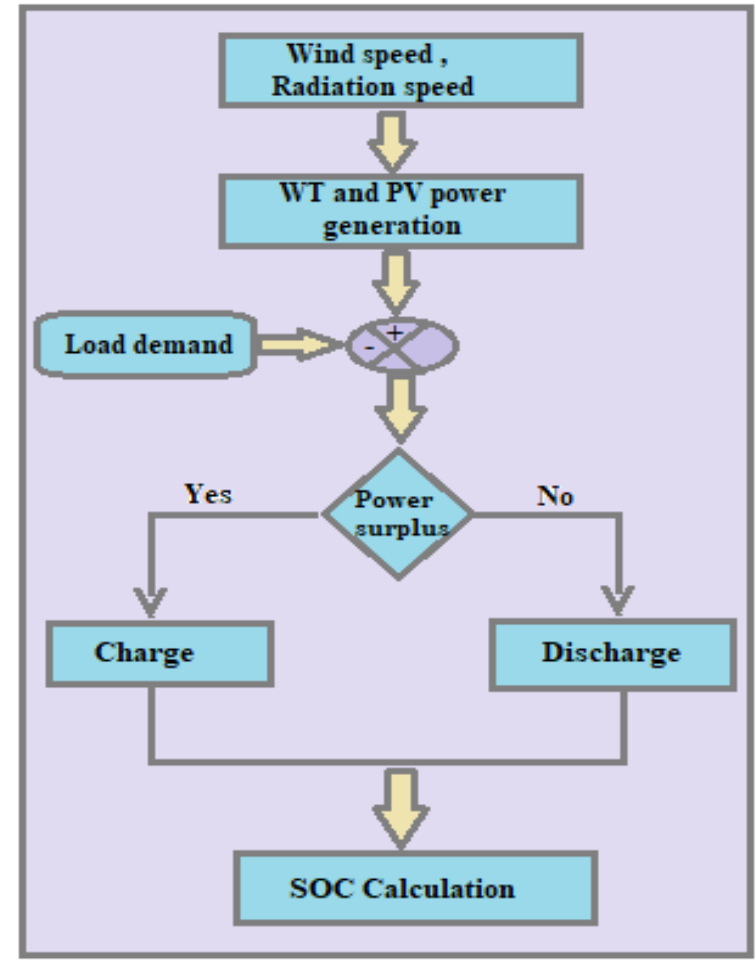

Figure 9. Algorithm of the control strategy.

\subsection{Control Strategy of the Ventilation/Heating System}

Several control strategies for electric motors have been developed [39], such as scalar control, predictive control, etc., but, in this study, a vector control is used. It can control the speed of the asynchronous motor, the electromotive flux, and the torque of the three-phase electric motor. In general, vector control consists of a PI controller which calculates the reference speed according to its rated speed; this technique is not stable for motor speed control since the motor speed of a load is variable over time [40,41].

For this reason, we developed a PI controller Optimized by Fuzzy Logic (PIOFL). The structure of the proposed vector control is reported in Figure 10. Firstly, a Fuzzy Logic (FL) controller is defined, then it is optimized by using PI controller.

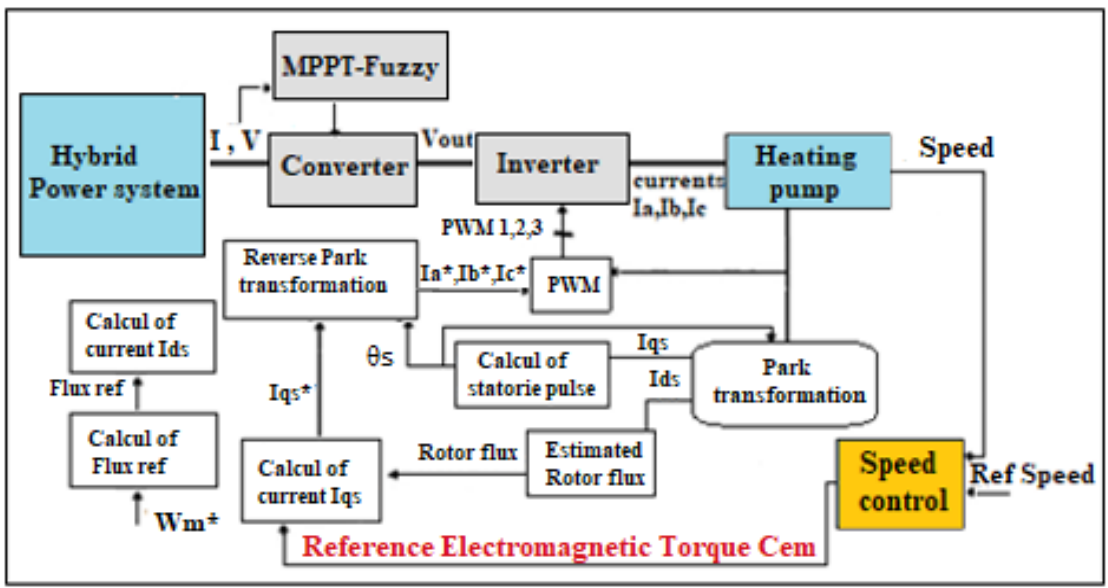

Figure 10. Scheme of the PI controller Optimized by Fuzzy Logic (PIOFL).

The diagram of the speed control strategy based on a basic FL controller is summarized in Figure 11, where two linguistic variables at the input of the speed controller are defined: 
the speed error $\mathrm{E}$ and sampled acceleration $\Delta \mathrm{E}_{\mathrm{T}}$. Speed error $\mathrm{E}$, at the $\mathrm{k}$-th step, is defined as:

$$
E(k)=\Omega_{r e f}-\Omega(k)
$$

where $\Omega_{\text {ref }}$ is reference speed and $\Omega$ is the actual speed of the motor, calculated as:

$$
\Omega(k)=\frac{1}{J \cdot p+f} \cdot\left[C_{e m}(k)-C_{r}(k)\right]
$$

with $J$ the inertia on the shaft of the heating system group, $p$ the Laplace variable, and $f$ the viscous friction coefficient; $C_{r}$ is the load (resistive) torque, while the electromagnetic torque, $C_{e m}$, is given by:

$$
C_{e m}(k)=C_{e m}(k-1)+\Delta C_{e m}(k)
$$

where $\Delta C_{e m}(k)$ is the output of the fuzzy logic controller.

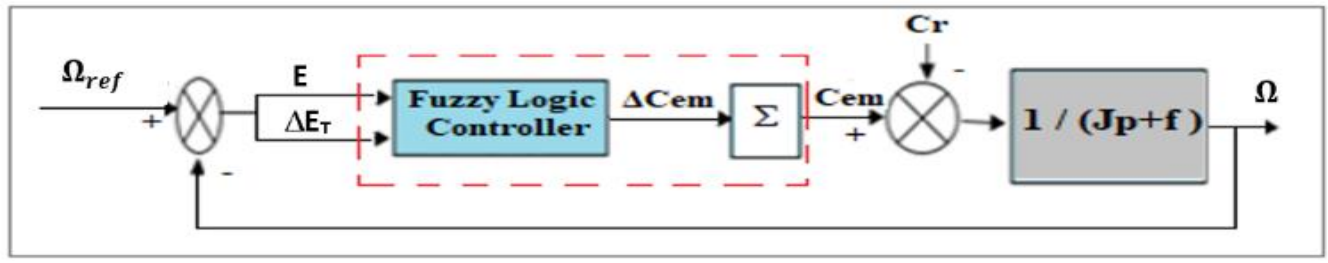

Figure 11. Basic FL controller for the yellow block in Figure 9.

The inference rules of the FL controller are reported in Table 3, where the first column reports the input error E of the FL controller, the second column the sampled acceleration $\Delta \mathrm{E}_{\mathrm{T}}$, while the third column regards the output of the fuzzy controller for $C_{e m}$. Based on the study of the behavior of the system in closed control loop, there are three fuzzy sets, which implies nine possible combinations of these inputs, or nine rules.

Table 3. Speed control inference rules.

\begin{tabular}{cccc}
\hline Rule $\mathbf{N}^{\circ}$ & $\mathbf{E}$ & $\Delta \mathbf{E}_{\mathbf{T}}$ & $C_{\boldsymbol{e m}}$ \\
\hline 1 & $\mathrm{P}$ & $\mathrm{P}$ & $\mathrm{P}$ \\
2 & $\mathrm{P}$ & $\mathrm{Z}$ & $\mathrm{P}$ \\
3 & $\mathrm{P}$ & $\mathrm{N}$ & $\mathrm{P}$ \\
4 & $\mathrm{Z}$ & $\mathrm{P}$ & $\mathrm{P}$ \\
5 & $\mathrm{Z}$ & $\mathrm{Z}$ & $\mathrm{Z}$ \\
6 & $\mathrm{Z}$ & $\mathrm{N}$ & $\mathrm{N}$ \\
7 & $\mathrm{~N}$ & $\mathrm{P}$ & $\mathrm{N}$ \\
8 & $\mathrm{~N}$ & $\mathrm{Z}$ & $\mathrm{N}$ \\
9 & $\mathrm{~N}$ & $\mathrm{~N}$ & $\mathrm{~N}$ \\
\hline
\end{tabular}

Now, FL can be a useful support in processing inaccurate variables and in minimizing objective decisions through approximate cognition. This controller has good robustness against external disturbances, but it is not quick. On the other hand, the PI controller has a fast response and is sensitive to external perturbations [42]. To take full advantage of both controllers, we program the coefficients of the PI controller optimized by fuzzy logic, as reported in Figure 12, i.e., similar to Figure 11, apart from the PI controller.

The inputs to the fuzzy controller are the same linguistic variables defined in Equations (37) and (38). Similarly, the fuzzification stage will also be retained. The difference with respect to the basic FL controller concerns the output linguistic variables. 


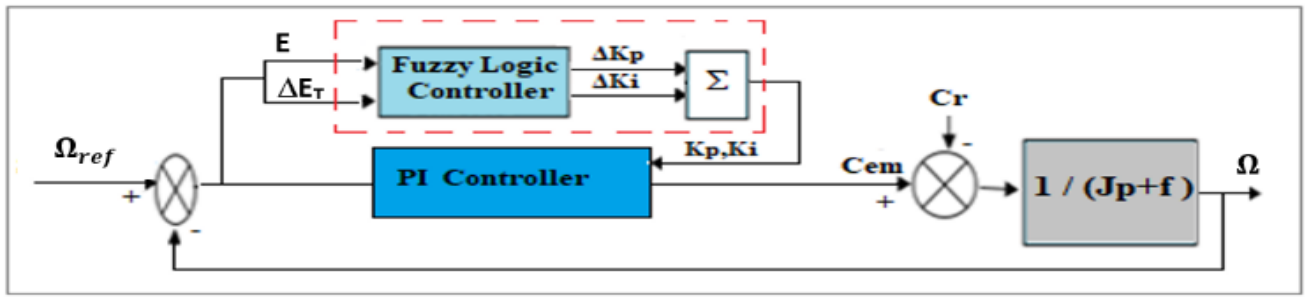

Figure 12. PI controller optimized by fuzzy logic for yellow block in Figure 10.

The inference rules that manage the controller level are detailed in Tables 4 and 5 for $\mathrm{Kp}$ and $\mathrm{Ki}$, respectively. The proposed control strategy consists of a PI controller with parameters $\mathrm{Kp}$ and $\mathrm{Ki}$ generated from a fuzzy controller to improve the robustness of the whole control. This robustness is due to the change of the parameters $\mathrm{Kp}$ and Ki every time a change of the input parameters occurs.

Table 4. Inference rules for Kp.

\begin{tabular}{ccc}
\hline Rule $\mathbf{N}^{\circ}$ & E & Kp \\
\hline 1 & $\mathrm{~N}$ & $\mathrm{~N}$ \\
2 & $\mathrm{Z}$ & $\mathrm{Z}$ \\
3 & $\mathrm{P}$ & $\mathrm{P}$ \\
\hline
\end{tabular}

Table 5. Inference rules for Ki.

\begin{tabular}{cccc}
\hline Rule $\mathbf{N}^{\circ}$ & $\mathbf{E}$ & $\mathbf{d E}$ & $\mathbf{K i}$ \\
\hline 1 & $\mathrm{P}$ & $\mathrm{P}$ & $\mathrm{P}$ \\
2 & $\mathrm{P}$ & $\mathrm{Z}$ & $\mathrm{P}$ \\
3 & $\mathrm{P}$ & $\mathrm{N}$ & $\mathrm{P}$ \\
4 & $\mathrm{Z}$ & $\mathrm{P}$ & $\mathrm{P}$ \\
5 & $\mathrm{Z}$ & $\mathrm{Z}$ & $\mathrm{Z}$ \\
6 & $\mathrm{Z}$ & $\mathrm{N}$ & $\mathrm{N}$ \\
7 & $\mathrm{~N}$ & $\mathrm{P}$ & $\mathrm{N}$ \\
8 & $\mathrm{~N}$ & $\mathrm{Z}$ & $\mathrm{N}$ \\
9 & $\mathrm{~N}$ & $\mathrm{~N}$ & $\mathrm{~N}$ \\
\hline
\end{tabular}

\section{Simulation Results and Discussion}

\subsection{Electrical Behavior of the PV Generator}

The PV module specifications under STC are shown in Table 6 [43]. The PV generator consists of several modules in series and in parallel, and it is simulated in the MATLAB/SIMULINK environment with real climatic data measured in the research laboratory in the Faculty of Sciences of Tunis, Tunisia. The PV generator is associated with the converter, controlled by MPPT-based fuzzy logic controller. During the simulation, the photovoltaic radiation varied between $0 \mathrm{~W} / \mathrm{m}^{2}$ and $800 \mathrm{~W} / \mathrm{m}^{2}$, with a temperature of $25{ }^{\circ} \mathrm{C}$. The role of the buck converter consists in decreasing the voltage to $24 \mathrm{~V}$ and extracting the maximum power delivered by the PV generator. The command of the FL is good and assures the MPPT in all the weather conditions. It is also fast and precise. Figure 13 presents the profile of the solar radiation, while Figure 14 shows the PV power and voltage. 
Table 6. Main parameters of the PV module Kaneka GSA060.

\begin{tabular}{cc}
\hline Technical Specifications & Nominal Values \\
\hline Nominal power, Pn & $60 \mathrm{Wp}$ \\
Minimum Power & $57 \mathrm{~W}$ \\
Voltage at Pmax, Vmpp & $67 \mathrm{~V}$ \\
Current at Pmax, Impp & $0.9 \mathrm{~A}$ \\
Open circuit voltage, Voc & $92 \mathrm{~V}$ \\
Short-circuit current, Isc & $1.19 \mathrm{~A}$ \\
\hline
\end{tabular}

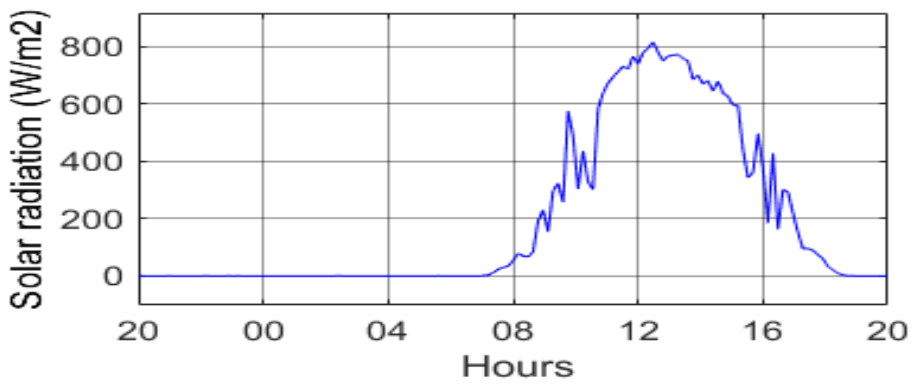

Figure 13. Solar radiation profile.
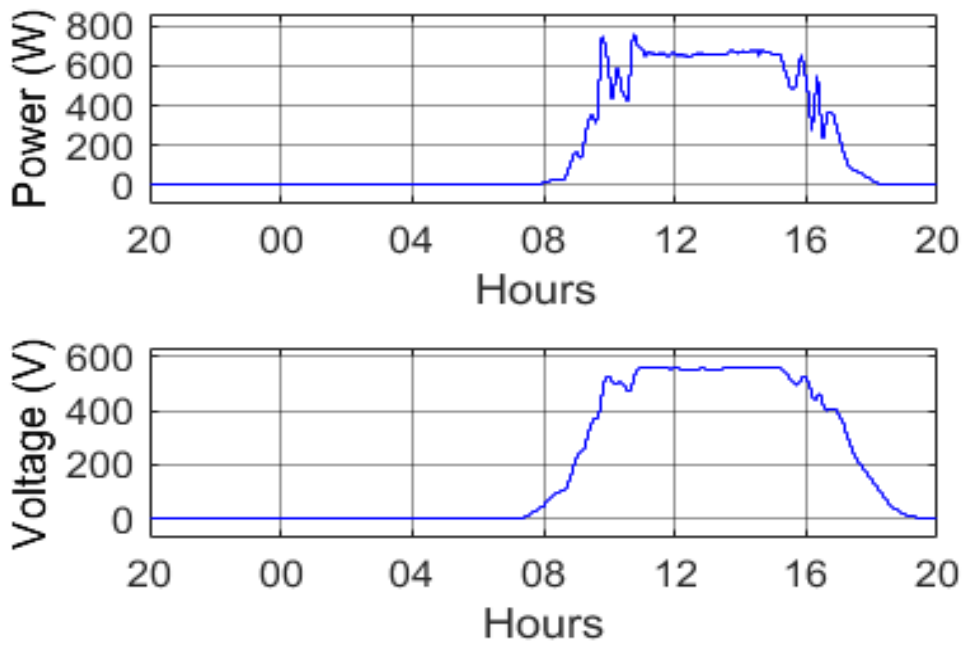

Figure 14. Power and voltage of the PV generator.

The simulation results show the efficiency of the MPPT command in the converter control such that the voltage is constant, and the power operates at a maximum power delivered by the PV generator.

\subsection{Electrical Behavior of the Wind Turbine}

The PMSG wind turbine system used in this simulation has the following specifications: $1 \mathrm{~kW}$ at $400 \mathrm{~V}, \mathrm{f}=50 \mathrm{~Hz}$, coupled with a SEPIC converter controlled by a fuzzy strategy. Figure 15 reports the Simulink model of the wind system. 


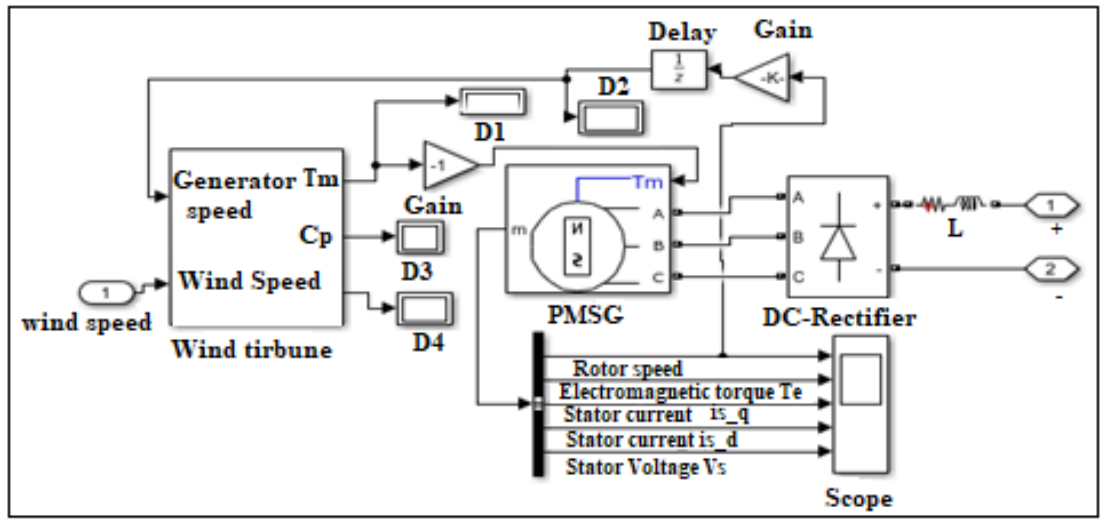

Figure 15. Simulink model of the wind turbine.

Figure 16 diagrams the real database of the wind speed, while the power and voltage of the wind turbine are reported in Figure 17.

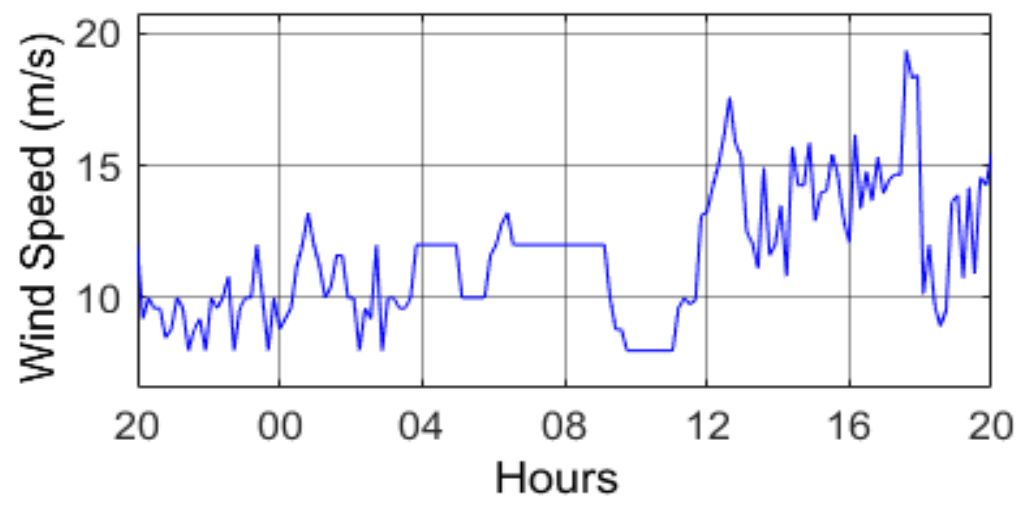

Figure 16. Wind speed profile.
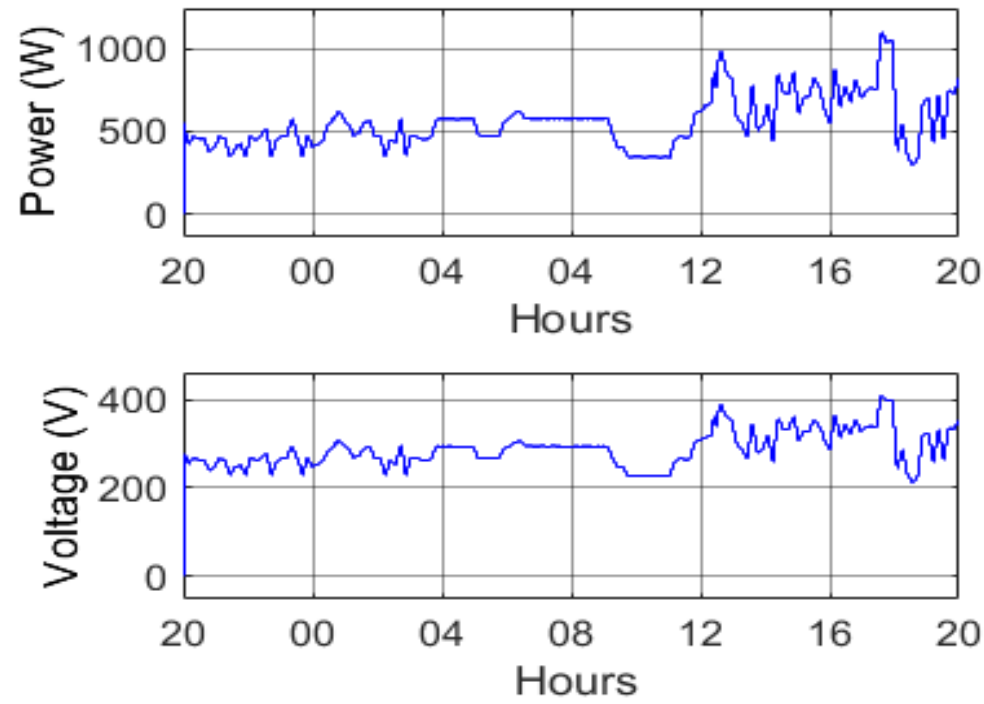

Figure 17. Power and the voltage of the wind turbine.

\subsection{Simulation of the MSPS under Control Strategy}

This section evaluates a MSPS consists of the PV generator (based on Kaneka GSA060) and a PMSG wind system, supported by the BESS, simulated under the MATLAB/SIMULINK environment. They are connected to a variable resistive load that absorbs a variable power between $700 \mathrm{~W}$ and $900 \mathrm{~W}$. 
The Li-Ion battery is constituted by three cells and has Vn $=200 \mathrm{~V}$, while its capacity is equal to $100 \mathrm{Ah}$. The SOC and DOD are variable during the simulation and the initial values are fixed to SOC $=60 \%$ (the battery is not totally charged) and DOD $=40 \%$.

The power of each MSPS component is shown in Figure 18, whereas Figure 19 reports the battery charging and discharging.

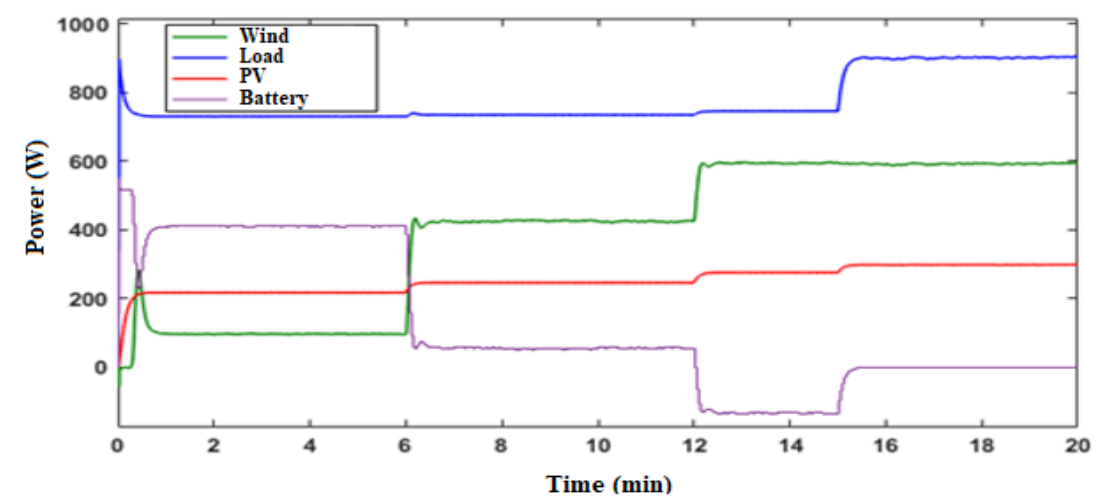

Figure 18. Power delivered by the MSPS.

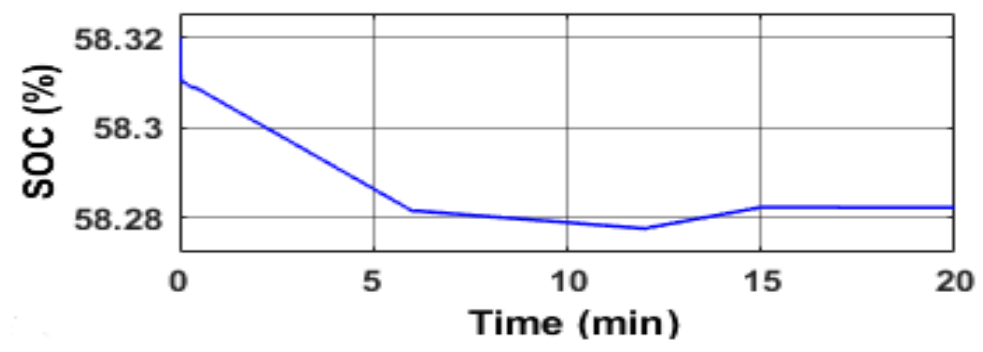

Figure 19. Battery charging and discharging.

During the period 0-6 min, the power of the load is set to $700 \mathrm{~W}$. The power delivered by the energy sources is equal to $300 \mathrm{~W}$ and BESS delivers $400 \mathrm{~W}$ (discharging) to balance the power absorbed by the load. The battery reaches its low SOC state (Figure 19). During the period 12-15 min, the power produced by the MSPS exceeds the power required by the load. In this case, the surplus power is stored in the battery (charging). After the 15th minute, the load power equals the power produced by the MSPS, indicating that the battery level is constant. It is concluded that the BESS and the proposed algorithm seem to provide a correct energy balance. In case of sudden changes, the proposed system reacts quickly to transience and avoids power oscillations.

Simulation results show the effectiveness of the proposed control strategy, while the BESS correctly manages the charging and discharging, on the basis of the load demand.

\subsection{Simulation Results of the Global System}

A real database of the values of solar radiation, outside temperature, and wind speed of one day (5 March 2017 in Tunisia) is used in the Simulink-based system. As the internal temperature of the greenhouse should vary in a limited range, two actuators are needed: a ventilation system to remove internal heat during the hot hours of midday, and a heating system to raise the internal temperature during the cold hours of the night.

Figures 20 and 21 show the simulation results of the output power and the voltage delivered by the MSPS under MPPT fuzzy controller, and the storage system battery coupled with a SEPIC converter. It injects power into the DC bus to ensure the operation of the actuators (ventilation and heating system). 


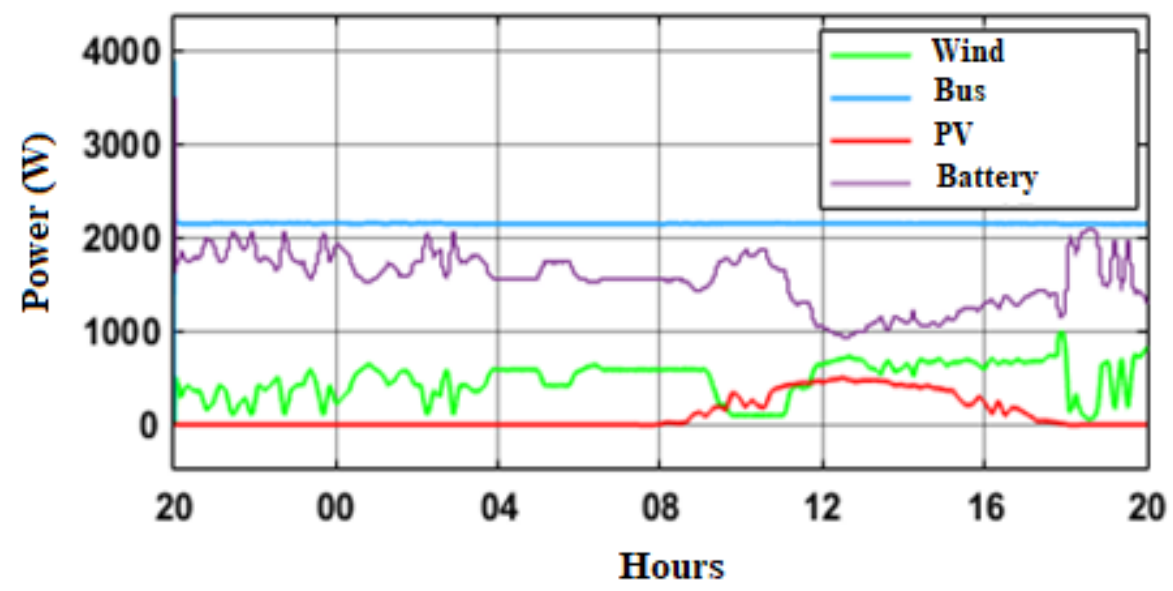

Figure 20. Power delivered by different sources of the MSPS and BESS.

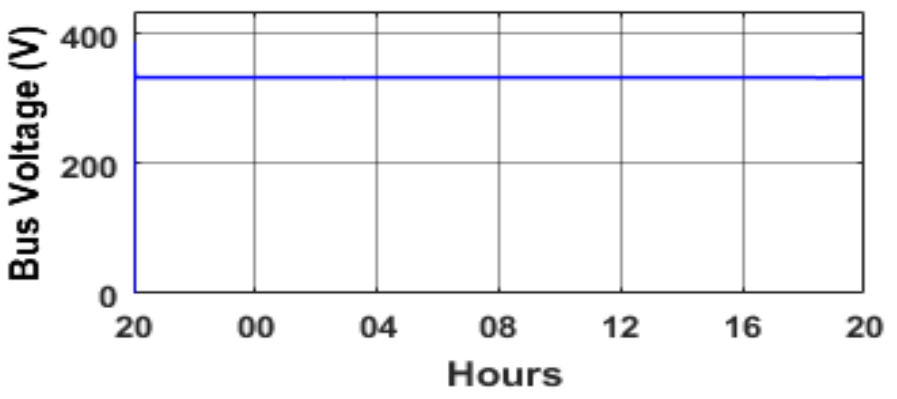

Figure 21. Voltage at the DC bus.

The real agricultural system under investigation is equipped with a ventilation system based on a three-phase asynchronous motor and a heat pump. Table 7 reports the electrical parameters of both the actuators used in the experimental energy system.

Table 7. Actuators.

\begin{tabular}{ccc}
\hline Actuator & Electrical Parameters & Nominal Power \\
\hline Ventilation System & 3 phase $-50 \mathrm{~Hz}$ & $705 \mathrm{~W}$ \\
\hline Heating system & $230 \mathrm{~V}, 50 / 60 \mathrm{~Hz}$ & $1000 \mathrm{~W}$ \\
\hline
\end{tabular}

The simulation results of the ventilation system are presented in Figures 22 and 23 From 12:00 am and 6:00 pm, the internal temperature of the greenhouse exceeds the reference temperature, $24^{\circ} \mathrm{C}$ [38]. Therefore, the ventilation system operates at maximum speed $(480 \mathrm{rpm})$ as shown in Figure 23. During this period, the MSPS delivers a maximum power $(1.6 \mathrm{~kW}$, see Figure 20) to ensure the operation of the ventilation system and to lower the indoor temperature to around its reference point.

Figure 24 shows the heating rate that the heating system must ensure to increase the internal temperature to the reference value during the night and the first hours of the day, until $11.00 \mathrm{am}$. The heating system should operate around the maximum speed to guarantee the maximum heating rate of $250 \mathrm{~W} / \mathrm{m}^{2}$. Figure 25 shows the motor speed of the heating system under the PIOFL controller. The energy is supplied by the wind system and the battery during the night, as you can observe in Figure 20. Moreover, PIOFL controller showed robustness in vector control, no overshoot, and a fast response when the reference speed changed. So, PIOFL is efficient for the proposed system control and is a good solution to reduce energy consumption in the agricultural greenhouse. 


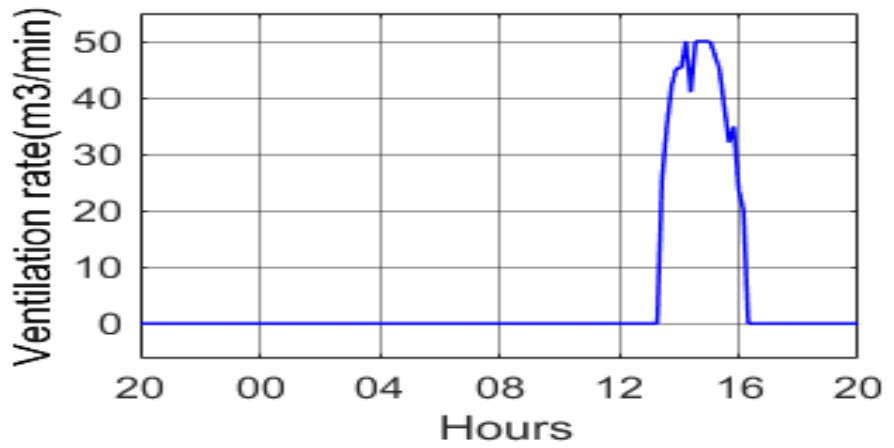

Figure 22. Ventilation rate.

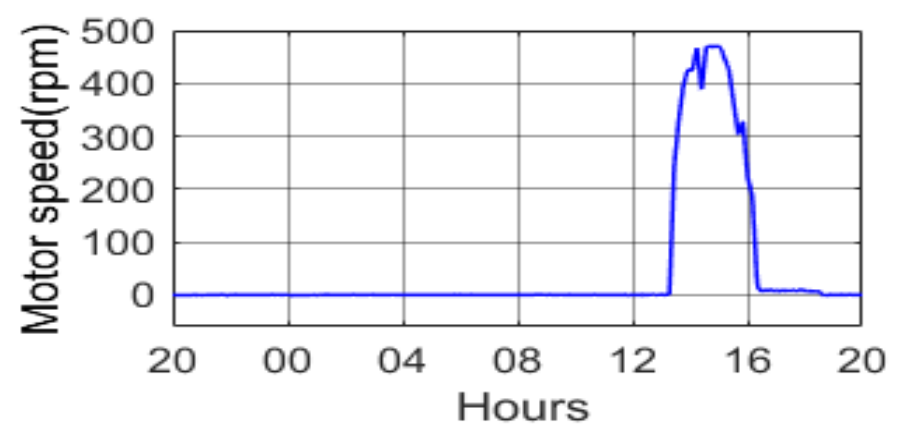

Figure 23. Motor speed of the ventilation system.

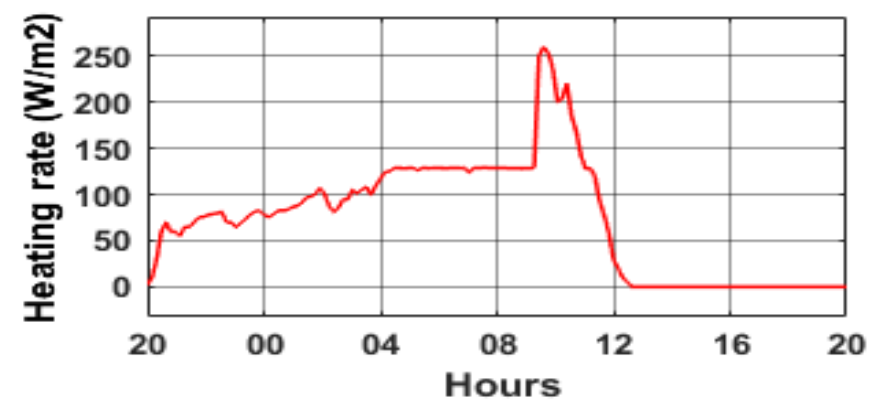

Figure 24. Heating rate of the greenhouse.

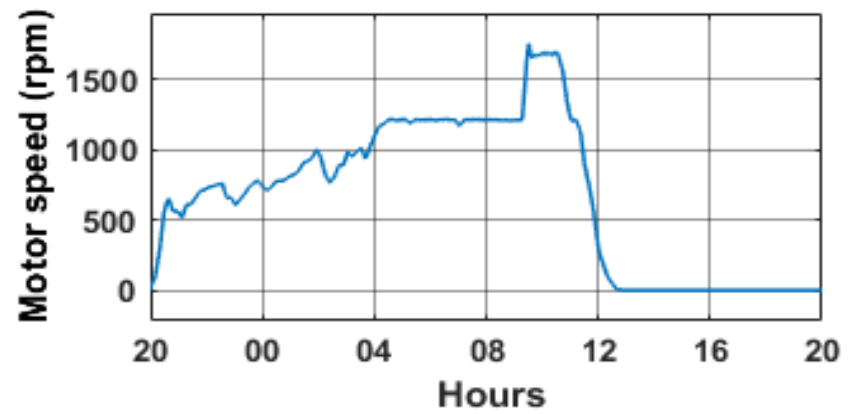

Figure 25. Motor speed of the heating system under PIOFL controller.

The absence of PV energy, during the night, has an impact on the control of the agricultural greenhouse. The wind turbine supported by the storage system works with a boost converter to guarantee the maximum power injected in the heating system through a DC bus. The simulation results of the MSPS show the effectiveness in controlling the greenhouse system for different periods of time. Moreover, the coupling of two RES and a 
storage battery system allows supplying the energy to the greenhouse during the whole day, and this implies an improved energy management.

Finally, Figure 26 reports the desired temperature in the greenhouse $\left(24{ }^{\circ} \mathrm{C}\right.$ during the day and $15^{\circ} \mathrm{C}$ during the night, black line), the real outside temperature and the real inside temperature. It shows that the control is effective in following the setpoint temperature.

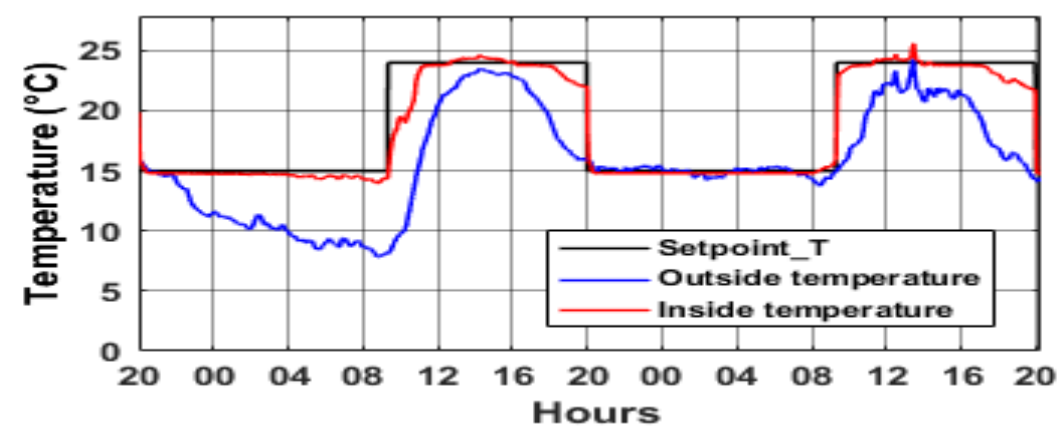

Figure 26. Temperature under ventilation and heating control.

In summary, Figures 18, 20 and 26 show that the main objectives have been achieved. Figure 26 shows that the desired temperature $\left(24{ }^{\circ} \mathrm{C}\right.$ during the day and $15^{\circ} \mathrm{C}$ during the night) is maintained until the next change and the transition between the two states is fast. Figure 20 shows how the single components contribute to the requested power: the PV plant gives an insufficient contribution only during the day, the wind plant gives a variable contribution during the $24 \mathrm{~h}$ period, and the battery closes the balance. Finally, Figure 18 shows the MSPS response to the variation of the power absorbed by the load and/or to the variation of the power produced by one component of the MSPS.

\section{Conclusions}

The paper is constituted by two main parts: the power sources and the control. The first part proposes a battery-PV-wind energy system to power the heating and ventilation system of an agricultural greenhouse. Each subsystem is an accurate and verified model: a temperature-dependent model for the PV generator, a wind turbine coupled with a PMSG generator, and a BESS that allows improvement of the performance of the MSPS, especially during the night when only the wind system-subject to rapid wind variations, because the greenhouse is located near the sea-supplies the electrical load. The second part introduces the PIOFL strategy to control the energy flows exchanged among power sources, electrical loads, and battery. The global system has been tested by inputting the real environmental data for a complete daily scenario, which must consider the contributions of both PV and wind generators during the day, and the contribution of only the wind generator during the night. The proposed PIOFL strategy has shown an accurate and reliable operation during the variations of the energy flows because the target was reached in a limited time and in any condition (with one or two power sources). Moreover, the PIOFL has shown its reliability in reaching the temperature target both in increasing and in decreasing the internal temperature. The MSPS is modelled in MATLAB/Simulink under the change in wind speed, solar irradiance, and load. The simulation results demonstrated that the proposed MSPS maintains active power balance between supply and demand irrespective of variations in solar irradiance, wind speed, and connected load. Moreover, VDC, frequency, and output AC voltage are very minimally impacted due to these variations. Future work will focus on the temperature dependence of the battery capacity, which is a critical issue for certain latitudes.

Author Contributions: Conceptualization, J.R., S.V., D.M. and A.M.; methodology, J.R., S.V., D.M. and A.M.; software, J.R., D.M.; validation, J.R., S.V., D.M. and A.M.; formal analysis, J.R., S.V., D.M. and A.M.; investigation, J.R., D.M.; resources, J.R. and A.M.; data curation, J.R., D.M.; writingoriginal draft preparation, J.R., S.V. and D.M.; writing-review and editing, S.V., D.M. and A.M.; 
visualization, J.R., S.V., D.M. and A.M.; supervision, S.V. and A.M.; project administration D.M. and A.M. All authors have read and agreed to the published version of the manuscript.

Funding: This research received no external funding.

Conflicts of Interest: The authors declare no conflict of interest.

\section{References}

1. Riahi, J.; Vergura, S.; Mezghani, D.; Mami, A. A combined PV-wind energy system for an energy saving greenhouse. In Proceedings of the IEEE International Conference on Environment and Electrical Engineering and 2020 IEEE Industrial and Commercial Power Systems Europe (EEEIC/I\&CPS Europe), Madrid, Spain, 9-12 June 2020; pp. 1-6.

2. Diab, F.; Lan, H.; Zhang, L.; Ali, S. An environmentally friendly factory in Egypt based on hybrid photovoltaic/wind/diesel/battery system. J. Clean. Prod. 2016, 112, 3884-3894. [CrossRef]

3. Huang, P.-H.; Kuo, J.-K.; Wu, Z.-D. Applying small wind turbines and a photovoltaic system to facilitate electrolysis hydrogen production. Int. J. Hydrogen Energy 2016, 41, 8514-8524. [CrossRef]

4. JFulzele, B.; Daigavane, M.B. Simulation and optimization of hybrid PV-wind renewable energy system. In Proceedings of the 3rd International Conference on Electrical, Electronics, Engineering Trends, Communication, Optimization and Sciences (EEECOS 2016), Tadepalligudem, India, 1-2 June 2016.

5. Allani, M.Y.; Jomaa, M.; Mezghani, D.; Mami, A. Modelling and simulation of the hybrid system PV-wind with MATLAB/SIMULINK. In Proceedings of the 9th International Renewable Energy Congress (IREC), Hammamet, Tunisia, 20-22 March 2018.

6. Gautam, A.R.; Mahela, O.P.; Singh, S.; Mahia, R.N. A double input SMV controlled dc/dc buckboost converter for solar $\mathrm{PV} /$ wind energy sources. In Proceedings of the International Conference on Recent Advances and Innovations in Engineering (ICRAIE-2014), Jaipur, India, 9-11 May 2014; pp. 1-6.

7. Qi, W.; Liu, J.; Chen, X.; Christofides, P.D. Supervisory Predictive Control of Standalone Wind/Solar Energy Generation Systems. IEEE Trans. Control Syst. Technol. 2011, 19, 199-207. [CrossRef]

8. Vergura, S.; Pavan, A.M. On the photovoltaic explicit empirical model: Operations along the current-voltage curve. In Proceedings of the IEEE-ICCEP 2015 International Conference on Clean Electrical Power, Taormina, Italy, 16-18 June 2015.

9. Vergura, S. Correct Settings of a Joint Unmanned Aerial Vehicle and Thermocamera System for the Detection of Faulty Photovoltaic Modules. IEEE J. Photovolt. 2021, 11, 124-130. [CrossRef]

10. Vergura, S.; Marino, F. Quantitative and Computer Aided Thermography-based Diagnostics for PV Devices: Part I-Framework. IEEE J. Photovolt. 2017, 7, 822-827. [CrossRef]

11. Vergura, S.; Colaprico, M.; de Ruvo, M.F.; Marino, F. A Quantitative and Computer Aided Thermography-based Diagnostics for PV Devices: Part II-Platform and Results. IEEE J. Photovolt. 2017, 7, 237-243. [CrossRef]

12. Sineglasov, V.M.; Dmitrenko, B.I.; Kulbaka, A.V. Using PV/wind hybrid systems in the autonomous power of unmanned aerial vehicle control centre. In Proceedings of the IEEE 2nd International Conference Actual Problems of Unmanned Air Vehicles Developments (APUAVD), Kyiv, Ukraine, 15-17 October 2013.

13. Maher, A.; Kamel, E.; Enrico, F.; Atif, I.; Abdelkader, M. An intelligent system for the climate control and energy savings in agricultural greenhouses. Energy Effic. 2016, 9, 1241-1255. [CrossRef]

14. Echaieb, K.; Azaza, M.; Mami, A. A new control strategy of indoor air temperature in a photovoltaic greenhouse. Int. J. Soft Comput. Softw. Eng. 2013, 3, 848-852.

15. Stoyanov, L.; Bachev, I.; Zarkov, Z.; Lazarov, V.; Notton, G. Multivariate Analysis of a Wind-PV-Based Water Pumping Hybrid System for Irrigation Purposes. Energies 2021, 14, 3231. [CrossRef]

16. Food and Agriculture Organization of the United Nations. Water for Sustainable Food and Agriculture: A Report Produced for the G20 Presidency of Germany. Available online: http:/ /www.fao.org/3/i7959e/i7959e.pdf?fbclid=IwAR1eV3HuHfHdxH6ca1 1yhMBTD6U78LnwqUxZ1KrTWaxfUgOQF4rpuFwJtWo (accessed on 13 August 2021).

17. Salisu, S.; Mustafa, M.W.; Olatomiwa, L.; Mohammed, O.O. Assessment of technical and economic feasibility for a hybrid PV-wind-diesel-battery energy system in a remote community of north central Nigeria. Alex. Eng. J. 2019, 58, 1103-1118. [CrossRef]

18. Krishan, O.; Suhag, S. Techno-economic analysis of a hybrid renewable energy system for an energy poor rural community. J. Energy Storage 2019, 23, 305-319. [CrossRef]

19. Wesly, J.; Brasil, A.C.P.; Frate, C.A.; Badibanga, R.K. Techno-economic analysis of a PV-wind-battery for a remote community in Haiti. Case Stud. Chem. Environ. Eng. 2020, 2, 100044. [CrossRef]

20. Gorjian, S.; Calise, F.; Kant, K.; Ahamed, S.; Copertaro, B.; Najafi, G.; Zhang, X.; Aghaei, M.; Shamshiri, R.R. A review on opportunities for implementation of solar energy technologies in agricultural greenhouses. J. Clean. Prod. 2021, $285,124807$. [CrossRef]

21. ATraoré, K.; Cardenas, A.; Doumbia, M.L.; Agbossou, K. Comparative Study of Three Power Management Strategies of a Wind PV Hybrid Stand-alone System for Agricultural Applications. In Proceedings of the IECON 2018-44th Annual Conference of the IEEE Industrial Electronics Society, Washington, DC, USA, 21-23 October 2018; pp. 1711-1716. 
22. Islam, A.; Merabet, A.; Beguenane, R.; Ibrahim, H. Power Management Strategy for Solar-Wind-Diesel Stand-alone Hybrid Energy System. Int. J. Electr. Comput. Energ. Electron. Commun. Eng. 2014, 8, 849-853.

23. Al-Ghussain, L.; Ahmed, H.; Haneef, F. Optimization of hybrid PV-wind system: Case study Al-Tafilah cement factory, Jordan, Sustain. Energy Technol. Assess. 2018, 30, 24-36. [CrossRef]

24. Singh, P.; Ravindra, N. Temperature dependence of solar cell performance-An analysis. Sol. Energy Mater. Sol. Cells 2012, 101, 36-45. [CrossRef]

25. Luque, A.; Hegedus, S. Handbook of Photovoltaic Science and Engineering; John Wiley and Sons: Chichester, UK, 2003.

26. Markvart, T.; Castaner, L. Practical Handbook of Photovoltaics. Fundamentals and Applications; Elsevier: Oxford, UK, 2006.

27. Vergura, S. Scalable Model of PV Cell in Variable Environment Condition based on the Manufacturer Datasheet for Circuit Simulation. In Proceedings of the IEEE-EEEIC 2015, Roma, Italy, 10-13 June 2015.

28. Vergura, S. A Complete and Simplified Datasheet-Based Model of PV Cells in Variable Environmental Conditions for Circuit Simulation. Energies 2016, 9, 326. [CrossRef]

29. Vergura, S. Hypothesis Tests-Based Analysis for Anomaly Detection in Photovoltaic Systems in the Absence of Environmental Parameters. Energies 2018, 11, 485. [CrossRef]

30. Joonmin, L.; Young-Seok, K. Sensorless fuzzy-logic-based maximum power point tracking control for a small-scale wind power generation system with a switched mode rectifier. IET Renew. Power Gener. 2016, 10, 194-202.

31. Charfi, S.; Atieh, A.; Chaabene, M. Modeling and cost analysis for different PV/battery/diesel operating options driving a load in Tunisia, Jordan and KSA. Sustain. Cities Soc. 2016, 25, 49-56. [CrossRef]

32. Allani, M.Y.; Tadeo, F.; Mezghani, D.; Mami, A. Modelling and Control of a Grid-connected Hybrid Photovoltaic/wind/battery System Coupled to an AC Load. IJSCNS 2019, 19, 5.

33. Borowy, B.S.; Salameh, Z.M. Methodology for optimally sizing the combination of a battery bank and PV array in a wind/PV hybrid system. IEEE Trans. Energy Convers. 1996, 11, 367-375. [CrossRef]

34. Daud, A.-K.; Ismail, M.S. Design of isolated hybrid systems minimizing costs and pollutant emissions. Renew. Energy 2012, 44, 215-224. [CrossRef]

35. Mezghani, D.; Othmani, H.; Mami, A. Bond graph modeling and robust control of a photovoltaic generator that powered an induction motor pump via SEPIC converter. Electr. Energy Syst. 2019, 29, e2746. [CrossRef]

36. Mezghani, D.; Mami, A.; Dauphin-Tanguy, G. Bond graph modelling and control enhancement of an off-grid hybrid pumping system by frequency optimization. Int. J. Numer. Model. 2020, 33, e2717. [CrossRef]

37. Riahi, J.; Vergura, S.; Mezghani, D.; Mami, A. Intelligent Control of the Microclimate of an Agricultural Grennhouse Powered by a Supporting PV System. Appl. Sci. 2020, 10, 1350. [CrossRef]

38. Ben Ali, R.; Bouadila, S.; Mami, A. Experimental validation of the dynamic thermal behavior of two types of agricultural greenhouses in the Mediterranean context. Renew. Energy 2019, 147, 118-129. [CrossRef]

39. Chen, M.; Zhang, W. H2 optimal speed regulator for vector-controlled induction motor drives. In Proceedings of the 27th Chinese Control and Decision Conference (2015 CCDC), Qingdao, China, 23-25 May 2015.

40. Miki, I.; Nagai, N.; Nishiyama, S.; Yamada, T. Vector control of induction motor with fuzzy PI controller. In Proceedings of the 1991 IEEE Industry Applications Society Annual Meeting, Dearborn, MI, USA, 28 September-4 October 1991.

41. Zhu, X.; Shen, A. Speed Estimation of Sensorless Vector Control System Based on Single Neuron PI Controller. In Proceedings of the 2006 6th World Congress on Intelligent Control and Automation, Dalian, China, 21-23 June 2006.

42. Othmani, H.; Mezghani, D.; Mami, A. Fuzzy Gain-Scheduling Proportional-Integral control for Improving the speed behavior of a three-phases induction motor. Int. J. Power Electron. Drive Syst. (IJPEDS) 2016, 7, 1161. [CrossRef]

43. Chaouali, H.; Othmani, H.; Mezghani, D.; Jouini, H.; Mami, A. Fuzzy logic control scheme for a 3 phased asynchronous machine fed by Kaneka GSA-60 PV panels. In Proceedings of the 7th IEEE International Conference Renewable Energy Congress, Hammamet, Tunisia, 22-24 March 2016. 